Socialist Studies: the Journal of the Society for Socialist Studies 5(2) Fall 2009: 41-63

Copyright (C) 2009 The Author(s)

SPECIAL SECTION ON RETHINKING LENINISM

\title{
Leninism: It's Not What You Think
}

\author{
PAUL KELLOGG \\ Department of International Development Studies, Trent University, Peterborough, \\ Ontario, Canada
}

\begin{abstract}
:
Leninism is universally understood as involving an emphasis on centralism and discipline inside the workers' party, a centralism and discipline necessary as a counter to the centralized power of the capitalist state. This article argues: 1) that Lenin's famous centralism was a necessity imposed on all socialists of his generation because of conditions of tsarist autocracy; 2) that when given the chance during moments of revolutionary upheaval, this centralism was pushed to the background, and a heavy emphasis was placed upon democracy and debate; 3) that late in life, Lenin realized that the 'Leninism' being aggressively promoted by the Communist International was too heavily weighted towards Russian conditions, and was a barrier to the development of the left outside of Russia; and 4) that this immanent critique of actually-existing Leninism was cut short and buried by the rise of Stalinism, for which an emphasis on centralism was a useful counterpart in party organization to the authoritarianism being constructed in the Stalinist state.

\section{Résumé:}

On pense généralement que le léninisme insiste sur le centralisme et la discipline dans le parti ouvrier, centralisme et discipline nécessaires pour contrer le pouvoir centralisé de l'état capitaliste. Cet article defend que: 1 ) le centralisme célèbre de Lénine était une nécessité impose à tous les socialistes de sa génération du fait de l'autocratie tsariste; 2 ) dès lors qu'il y avait un espace pendant les moments de bouleversement révolutionnaire, ce centralisme était mis en retrait et un accent lourd était mis sur la démocratie et le débat; 3 ) plus tard dans sa vie, Lénine a réalisé que le 'léninisme' qui était promu d'une façon agressive par l'Internationale communiste était trop lourdement biaisé par le contexte russe et que ceci était une barrière au
\end{abstract}

Paul Kellogg, Ph.D. (Queen's), M.A. (York), teaches in the Department of International Development Studies at Trent University. Recent publications include 'The only hope of revolution is the crowd: The limits of Žižek's Leninism' (International Journal of Žižek Studies 2, no. 2, 2008) and 'Regional Integration in Latin America: Dawn of an Alternative to Neoliberalism?' (New Political Science 29, no. 2, 2007). He can be reached at paulkellogg@trentu.ca.

Paul Kellogg, Ph.D. (Queen's), M.A. (York), enseigne dans le département d'études sur le développement international à l'université de Trent. Parmi ses publications récentes, 'Le seul espoir de révolution est la foule : les limites du léninisme de Žižek' (en anglais; International Journal of Žižek Studies 2, no. 2, 2008) et 'Intégration régionale dans l'amérique latine: I'aube d'une alternative au néolibéralisme?' (en anglais; New Political Science 29, no. 2, 2007). II peut être contacter à paulkellogg@trentu.ca. 
Socialist Studies: the Journal of the Society for Socialist Studies 5(2) Fall 2009: 41-63

\author{
développement de la gauche en dehors de la Russie; et 4) cette critique immanente du \\ léninisme en place a été muselée et enterrée par l'ascension du stalinisme, pour qui \\ l'accent sur le centralisme était un parallèle utile dans l'organisation du parti à \\ l'autoritarisme en construction dans l'état staliniste. \\ Keywords \\ - Lenin • democracy • democratic centralism • Leninism • Russia \\ Mots clés \\ - Lénine • démocratie • centralisme démocratique • léninisme • Russie
}

'There is no question that literature is least of all subject to mechanical adjustment or levelling, to the rule of the majority over the minority. There is no question, either, that in this field greater scope must undoubtedly be allowed for personal initiative, individual inclination, thought and fantasy' (Liebman 1975, 50-51). This was a comment on criteria for socialist publications written by a Russian socialist the year following the great 1905 revolution.

The author goes further. S/he has the following comments on internal party organization, arguing that 'the principal organizational units of the Party' must be 'the local organizations... in fact, and not merely in name,' going on to insist that 'all the higher-standing bodies' should be 'elected, accountable, and subject to recall' (51). Further, 'the autonomy of every Party organization, which hitherto has been largely a dead letter, must become a reality.'

Contrast this with the viewpoint of the Third Congress of the Communist International (or Comintern) in 1921. 'The leading Party district committee and, ultimately, the central leading body of the Party controls the activity and the correct functioning and composition of all the committees subordinate to it' (Koenen 1983, 256). Now that is much more familiar to us, a clear precondition for what the American Leninist, James Cannon, called, 'the Bolshevik discipline, the iron hardness, the capacity for decisive action... which a party of Leninism must have' (Cannon 1924).

Here's the problem - the advocate of fantasy in the pages of the socialist press, the advocate of the autonomy of every Party organization, the advocate of seeing the local organizations as the principal units of the Party - that advocate was the original Leninist, Vladimir Lenin (Lenin 1978a, 46; 1978b, 376). And Lenin's considered response to the 'hard Leninism' of the Third Congress of the Comintern ('considered' because a year earlier he had praised the resolution uncritically) is worth quoting at length: 
The resolution is an excellent one, but it is almost entirely Russian... everything in it is based on Russian conditions ... I am sure that no foreigner can read it... they will not understand it because it is too Russian ... because it is thoroughly imbued with the Russian spirit... [1]f by way of exception some foreigner does understand it, he cannot carry it out.... [W] made a big mistake with this resolution... we blocked our own road to further success (Lenin 1980, 418).

This is evidence, this article argues, of a discontinuity - a very large discontinuity - between what most people think Leninism is (the authoritarian, top-down, steel-hard party) and the 'Leninism' that Lenin himself thought appropriate for liberal democracies in advanced capitalist societies: party organization that allowed tremendous scope for debate, disagreement and discussion, party organization where the central unit was not the Central Committee, but the local organization, party organization imbued with democracy from top to bottom. The tremendous value of Marcel Liebman's now classic study, Leninism under Lenin, is that he - more than any other author - clearly highlights this discontinuity. The Leninism with which we became acquainted in the liberal democracies of the West was not the Leninism being advocated by, amongst others, Vladimir Lenin.

There is another reason to base this article in large part on Liebman. There is a new and welcome revival of Lenin scholarship that is attempting to peel back the misconceptions and abuses of past analyses, and finally to place our understanding of Lenin in a clear light, one that avoids both demonization and idolatry. Lars T. Lih - insisting on contextualizing the debates of the Russian left, very much in the spirit of Liebman - has written a detailed, scholarly recreation of the context and meaning of the oft-misunderstood What is to be Done? (Lih 2006). However, not all scholars are using such an approach. Slavoj Žižek is probably getting more sound bites than any other figure in the new revival of Lenin studies. The difficulty is that Žižek's interpretation of Lenin repeats many of the mistakes made by Leninists in the 1970s - including a romanticization of the role of the individual - Lenin - and a picture of Leninist organizational theory which shows little sensitivity to the way Lenin himself was aware of the very different kind of party organization required in the liberal-capitalist 'West.' Even worse, in his Revolution at the Gates (Žižek 2002) he has a confusing and at times insulting section with the appalling title, 'The Inner Greatness of Stalinism' (165-336).

In our generation's revival of Lenin studies we need to bring back the best of the last generation (critical scholarship along the lines of Liebman) and avoid the pitfall of re-linking Lenin to Stalin. This article both 
Socialist Studies: the Journal of the Society for Socialist Studies 5(2) Fall 2009: 41-63

re-introduces a new generation to the careful scholarship of Marcel Liebman, and in so doing paints a picture of the 'pro-fantasy' Lenin about which so little has been developed in the 'Leninism' which made its way to the West. There is a complex and buried lived history of Lenin and the original Leninists that - taken seriously - demands a sharp rethinking of our inherited conception of Leninism, and for those who have been influenced by Leninism, a careful rethinking of what 'Leninism' means in the context of liberal democracies in advanced capitalism.

\section{Recontextualizing Lenin}

It is important, Liebman argues, 'not to separate the doctrine from the historical setting in which it arose and developed. An analysis of Leninism must be a history of Leninism in its living evolution, and no history of Leninism can be separated from the history of the Russian revolution' (Liebman 1975, 21). By contrast, many 'works concerned with his teachings tend to isolate them from their historical context' (21). When theory and practice are decontextualized and artificially transplanted into extremely different conditions, when party organization is so 'thoroughly imbued with the Russian spirit' that either the non-Russian 'will not understand it' or if s/he understands it 'cannot carry it out', the result is, at best, a caricature.

With this method, we can examine the legendary 'authoritarianism' of Leninist organization. From 1903 on, the Russian socialists were divided into two principal groups, the Bolsheviks (Lenin's section) and the Mensheviks. Up to 1905, the Bolsheviks were organized in an extremely centralized fashion. In particular, the committees 'made up exclusively of professional revolutionaries' had 'almost unlimited powers' in relation to other members of the Party. In selecting local committees and structures, 'the principle of co-option' - that is of leading bodies selecting people, as opposed to having them elected by the membership - 'was applied "from top to bottom"' (44). However, these two characteristics - 'the important role played by the committees, and the absence of any electoral procedure... was characteristic of all Russia's socialist organizations down to 1905 ' (45). There was nothing specifically 'Leninist' about this - it was simply a question of survival. In later years, two leading Russian socialists - Georgi Plekhanov and Julius Martov - were to become critics of Lenin's methods. But in the early 1900s, these two 'were also agreed in considering that, in the circumstances prevailing in Russia, any revolutionary, or indeed any political organization must depend for its 
strength upon centralization; for them, the need for cohesion and secrecy had to be given priority over the desire for large-scale recruiting' (28-29).

The 'circumstances prevailing' would be completely foreign to activists whose experience is confined to liberal democracies in the advanced capitalist world. Russia was an autocracy. Socialist work was carried out underground. Most of the leading members were in exile - in Western Europe if they were lucky, in the misery of Siberia if they were not. Arrests were constant. Liebman, in another of his excellent books, paints an extremely clear picture of the circumstances in which Russian socialists operated.

It was the twentieth century, but at the far side of Europe, Russia was still in many respects in the Middle Ages; poverty and ignorance continued unchecked... In pre-revolutionary Russia, autocracy was... maintained by brute force and often by sheer terror. The Tsarist regime was permanently identified with the negation of all liberties.... [T] he very notion of freedom seemed incompatible with Tsarism. None of the political liberties that had long since been written into Western law existed in Russia before the 1905 Revolution. No opposition of any form was tolerated ... (Liebman 1970, 15-23).

Lenin had 'constant trouble' in getting his paper 'Iskra into the [Russian] empire. Trusted persons returning legally were provided with doublebottomed trunks ... Or there was an outright smuggling through the frontier post'. All of this 'tended to multiply the usual hazards of revolutionary and conspiratorial existence. The archives of the Tsarist police make it clear that they were very well informed as to the identity of many agents ... Frequent arrests disrupted the network' (Ulam 1971, 167168).

These conditions affected socialists, no matter what their organization. 'As a report by a Russian socialist to the Second International put it, "We fall not only in bloody fights, but also while printing our pamphlets, while selling books, distributing journals and tracts, speaking at meetings, holding conferences ... The average life of a committee is one to two months, that of a paper, one to two issues"' (Liebman 1970, 64).

Economically, Russia was equally far removed from advanced capitalism. The vast majority of the population was made up of peasants, only achieving emancipation from serfdom in the 1860s. Before emancipation, in the first half of the 19th century, serfs had an 'average death rate in excess of 40 per 1,000, a figure more than one-third higher than that of southern slaves [under plantation slavery in pre-civil war United States] and similar to that of Caribbean slaves. Especially appalling 
Socialist Studies: the Journal of the Society for Socialist Studies 5(2) Fall 2009: 41-63

was the mortality of young children... official statistics from Orel province [showed that] 60.9\% of the province's recorded deaths in 1858 were of children five and under' (Kolchin 1987, 153).

In Peter Kolchin's magnificent comparative study of serfdom in Russia and plantation slavery in the United States, there is a graphic description of the bitter reality of serf life in winter.

[P]easant huts... were small, and their dominant feature was the stove that served not only as a place to prepare food but more important as a source of heat near - and on - which family members huddled and slept. In summer peasants often escaped their teeming quarters to sleep out of doors 'in hay lofts, in sheds, in the yard,' but most of the year they crowded together for warmth. 'The peasant family in the winter lives in the same hut as its cattle,' wrote one observer, who noted the prevalent 'dampness and stench' as well.... [W] rote another... 'the pregnant, sick, old, and young' rarely ventured far from [the stove in winter] (Kolchin 1987,151).

Liberation from serfdom was an important step, but life in the countryside remained extremely miserable. Semyon Ivanovich Kanatchikov described his 'free peasant' childhood in grim, sardonic, prose.

My early childhood was not accompanied by any particularly outstanding events, unless one counts the fact that I survived; I wasn't devoured by a pig, I wasn't butted by a cow, I didn't drown in a pool, and I didn't die of some infectious disease the way thousands of peasant children perished in those days... my own mother, according to some sources, brought eighteen children into this world - according to others the number was twelve - yet only four of us survived (Kanatchikov 1986, 1).

Kanatchikov was one of hundreds of thousands who left these miserable conditions to migrate to industry and the cities. But for the first generations to escape to the cities, life was still miserable, and far removed from the reality of advanced capitalism.

Our workday at the factory lasted eleven and a half hours, plus a one-and-ahalf-hour lunch break. In the beginning I would grow terribly tired so that as soon as I got home from work and ate dinner, I would fall into my filthy, hard, straw-filled sack and sleep like a dead man, despite the myriad bed bugs and fleas.... We rented the apartment communally, as an artel of about fifteen men.... [My] room contained two wooden cots. One belonged to Korovin, my countryman and guardian; the other I shared with Korovin's son Vanka.... All fifteen men ate from a common bowl with wooden spoons. The cabbage soup contained little pieces of meat. First, they would ladle out only the soup then, when the soup was almost all gone, everyone tensely awaited a signal. A 
moment later someone would bang his spoon against the edge of the soup basin and say the words we were waiting for: 'Dig in!' Then began the furious hunt of the spoons for the floating morsels of meat. The more dexterous would come up with the most (Kanatchikov 1986, 9).

It has been necessary to spell out in some detail these political, social and economic conditions. Too often they are ignored, or at least underappreciated. These conditions cannot just be a footnote. An honest theorist has to attempt to assimilate them in their entirety. Without such an attempt, analyses of 'Leninism' are completely one-dimensional, completely formal, scholastic and empty. These are the 'Russian conditions' that Lenin warned would be incomprehensible to 'foreigners'.

Now Lenin, in making this warning, did not indicate exactly which 'foreigners' would have a difficult time 'translating from the Russian.' But we can have no doubt that he was referring to the socialists operating in the advanced capitalist countries - Britain, France and particularly Germany. As early as 1918 he had argued that 'our salvation... is an allEurope revolution... it is the absolute truth that without a German revolution we are doomed' (Lenin 1977b, 95, 98). He was also aware then - certainly not as clearly as in 1922, but certainly aware - that 'the world socialist revolution cannot begin so easily in the advanced countries as the revolution began in Russia' (Lenin 1977b, 98) that conditions in Germany, France and Britain were quite different from those in Russia: '[I]n a country in which capitalism is developed and has given democratic culture and organisation to everybody, down to the last man... there we are only just approaching the painful period of the beginning of socialist revolutions' (Lenin 1977b, 99).

In his 'too Russian' speech of 1922, he is underlying and amplifying this fact. There could be no straight line drawn between Tsarism and liberal democracy, between Russian economic backwardness and West European economic development. Similarly, there could be no straight line drawn between the organizational conclusions developed by the Russian socialists as a survival mechanism, and the organizational requirements of socialists operating in liberal democracies inside advanced capitalist economies. Given these 'Russian conditions,' who could argue with the need for a tight, top-down, centralized organization? In fact, as was pointed out above, serious socialists did not so argue. The elective principle and open organizational forms did not operate with either the Bolsheviks or the Mensheviks. To do so would have meant infiltration by the secret police, collapse and failure. 
Socialist Studies: the Journal of the Society for Socialist Studies 5(2) Fall 2009: 41-63

\section{5 and the 'democratic centralist moment'}

However - what would happen if these conditions were suddenly to transform into their opposite? That is precisely what happened - briefly during the revolutionary upsurge of 1905-06, and in that changed context 'Leninism' became unrecognizable.

The revolution of 1905 was a social and political earthquake. The year opened with a horrible massacre, when Tsarist soldiers opened fire on hundreds of thousands of demonstrating workers, killing hundreds. A massive wave of sympathy strikes swept the country, receded, and then exploded again in September with a strike of typesetters, followed by a general strike, followed by the beautiful establishment of the St. Petersburg Soviet, or Workers' Council. Thoroughgoing, city-wide democracy under the leadership of the urban working masses emerged for only the second time in history (the first being the Paris Commune thirty-five years earlier). In this context, Tsarist repression was for a moment swept aside. Public debate was everywhere, the socialist parties could operate openly, exiles could return to Russia, meetings could happen, newspapers could be sold - it was a flowering of freedom never before seen in the country.

'The upheaval in the country in 1905,' writes Liebman,

entailed an upheaval hardly less thoroughgoing in the Party. 'It will be necessary in very many cases to start from the beginning,' Lenin declared in November 1905. This will to renovation found expression in the democratizing of the Party's structures and methods. As Martov testifies, 'the leaders of both factions applied themselves with vigour to getting the elective principle accepted' (Liebman 1975, 49).

The British socialist Tony Cliff documents how this opening up of the party put Lenin up against the very Leninists formed in the earlier period. At the third congress of the Bolshevik Party in the spring of 1905, Lenin lost a vote to open up the party to the newly radicalizing workers:

Most of the delegates to the Congress were committee-men who were opposed to any move which would tend to weaken their authority over the rank and file. Buttressing themselves with quotations from What is to be Done? (a text written by Lenin in 1901 and 1902, usually seen as the 'textbook' for those seeking a centralized party based on professional revolutionaries), they called for 'extreme caution' in admitting workers into the committees and condemned 'playing at democracy' (Cliff 1975, 175). 
Lenin eventually won the argument - arguing often against ideas he had helped formulate - the gates of the party opened, and a new democratic structure and practice swept aside those of the past:

The Bolshevik congress of 1905 declared in favour of 'the autonomy of the committees' in relation to the Central Committee, whose authority was seriously pruned... At the head of the socialist movement in Petersburg a conference was placed - an elected body, meeting at least twice a month, subject to re-election every six months, and itself electing the Party Committee in the capital... Lenin recommended that, as a general rule, a 'referendum in the Party' should be carried out where any important political question was concerned (Liebman 1975, 50).

Riding the wave of revolution, his party and all the left parties grew impressively. 'In January 1905, on the eve of the revolution, the Bolshevik organizations had 8,400 members altogether. By the spring of 1906 the total membership of the RSDLP [the Russian Social Democratic Labour Party] stood at 48,000, of whom 34,000 were Bolsheviks and 14,000 Mensheviks. In October the total membership exceeded 70,000' (47). This revolutionary tide created pressures none of the party leaders could ignore, pressures in particular to end the split between the Bolsheviks and the Mensheviks, a split which had developed in confusing circumstances in 1903. So at Stockholm in 1906, the Bolsheviks and Mensheviks re-united into one socialist organization.

Now, it is not uncommon to recognize 'discipline' and 'centralism' as features of Leninism. But perhaps the most recognizable phrase in the dictionary of Leninism is the term 'democratic centralism.' What few realize is that this term was not developed by Lenin during the period of repression and tight centralization. It was not, in other words, a term used to insist on the necessity of centralism as part of a polemic against too loose an organizational structure and too much democracy. It was a term first introduced in 1906 at the unity Congress, in the period of revolution in 1905 and 1906 as part of a polemic against too much centralism, too tight an organizational structure and too little democracy.

Lenin said, in his report to the 1906 unification congress 'that there was still work to be done to "really to apply the principles of democratic centralism in Party organization, to work tirelessly to make the local organizations the principal organizational units of the Party in fact and not merely in name, and to see to it that all the higher-standing bodies are elected, accountable and subject to recall."' The application of democratic centralism 'implies universal and full freedom to criticize, so long as this 
Socialist Studies: the Journal of the Society for Socialist Studies 5(2) Fall 2009: 41-63

does not disturb the unity of a definite action' (Liebman 1975, 51). This didn't just mean criticism in the privacy of internal Party meetings. 'Criticism within the limits of the principles of the Party Programme must be quite free... not only at Party meetings, but also at public meetings. Such criticism, or such 'agitation' (for criticism is inseparable from agitation) cannot be prohibited' (Lenin 1978c, 442-443).

For Liebman, Lenin's synthesis of criticism and action is clear: 'Freedom of discussion, unity of action. What still needed to be clarified was, who was to have the power to issue these "calls for action"? ... Lenin's answer was clear: only the Party Congress possessed such power. At the same time, however, Lenin thought it was legitimate, in certain circumstances, to "fight ideologically against those decisions of the Congress which we regard as erroneous"' (Liebman 1975, 51-52).

This insistence on openness and democracy really should not be surprising. The construction of a socialist organization is part of a counterhegemonic project. The hegemony it is countering is one where centralism is ubiquitous. This is embedded in the structures of the economy, which are organized in a completely centralized, hierarchical, anti-democratic fashion. There is, however, the important reality of democracy in formal state structures. This is a product of generations of struggle. But this democracy is kept within very strict limits, too often being more formal than real. Given the authoritarian nature of the private, capitalist economy and the restricted nature of formal, political democracy, it is not surprising that apathy, deference, subservience and passivity are everyday realities of life under capitalism. Under conditions of autocracy they are enforced through coercion. But since the time of Gramsci, we have become all too aware of the way in which they can, in liberal democracies, be just as easily - and sometimes more easily - enforced through consent. This then reinforces the centralism that is also ubiquitous. Apathy, deference, subservience and passivity are necessary accompaniments to centralism and hierarchy. We see this everywhere. Bureaucratic decision-making in the state apparatus is a completely hierarchical, centralized process. Churches are built from the top down. Unions again and again evolve into centralized, undemocratic, bureaucratically-run machines. The truth is, we get very little exposure to consultation and democracy in the normal course of life in capitalist society. Centralism is part of our DNA. Democracy is not. It should not be surprising, then, that when possible, a counterhegemonic political project needs to put a strong emphasis upon creating and nurturing democratic structures. 
This was certainly the orientation for the Lenin shaped by the Revolution of 1905. But this aspect of Lenin's practice - the insistence on local autonomy, on freedom of criticism (in public and in private), on frequent elections and frequent meetings to make actual the accountability of elected committees - this aspect of Lenin's practice is almost never mentioned, let alone analyzed. Perhaps this is because centralism comes much easier to those whose only experience is that of capitalism. Centralism is the easy part. Democracy is what it will take a fight to achieve. Whatever the reason, Liebman's book was, and is, an indispensable corrective to a century of Leninology.

\section{Tsarism and Stalinism}

Among the reasons for the silencing of the democratic, 'pro-fantasy' Lenin, two in particular need to be highlighted. The first is the overwhelming weight of the life experiences of Lenin and his generation, experiences dominated by conditions that demanded harsh centralism in organization questions. The second is the long night of Stalinism. A particularly authoritarian version of 'Leninism' was the perfect party organizational counterpart to the extreme totalitarianism of Stalin's Russia.

In terms of Lenin's life experiences, the difficulties confronting socialists in Russia have already been outlined. Lenin was introduced to politics through the execution of his brother, had the 'luxury' of working out his political economy because of the peace and quiet of exile in Siberia, and spent most of his pre-revolutionary life in exile to escape from the Tsarist police. The 1905-1906 flowering of de facto political liberty was an all too-brief window into open, public, democratic organizing. First in Moscow, in the savage repression which followed the armed uprising in December 1905, and then by stages elsewhere in the country, reaction began to reassert itself. By 1907, the tsarist regime was on the offensive, rolling back the workers' gains, and the impact was staggering. Socialist organizations inside Russia were infiltrated by the secret police, and shattered. Many socialists - including Lenin - had to return to exile, where most lived in abject poverty, despair and isolation (Cliff 1975, 235-252). In such conditions, talk of the elective principle, frequent meetings, widescale recruitment and all the other accoutrements of the 'democratic centralist moment' were impossible. The party survived this period, rebuilt itself during the working class upsurge of 1912-14, only to be again forced underground during the horror of world war. It was, in other words, a party forged in conditions unimaginable to socialists in today's liberal 
Socialist Studies: the Journal of the Society for Socialist Studies 5(2) Fall 2009: 41-63

democracies. Not surprisingly, the organizational forms the Russian socialists had to adopt were harsh, and, to our eyes, 'authoritarian.' In a certain sense this 'authoritarianism' is not the surprising thing. How could it be otherwise, in a situation where any 'openness' would be exploited by the repressive state? What is surprising, is that in the brief 'democratic centralist moment' of 1905-1906, Lenin absolutely enthusiastically reached towards decentralization and democracy, and that again even in the harsh 1922 conditions in a workers' state surrounded by hostile imperialism, he could see clearly the need not to mechanically transplant organizational norms appropriate to Russian Tsarism onto the democratic, advanced capitalist stage of Western Europe.

Given the weight of a lifetime's experience, where democracy was a luxury and centralism a necessity, it is perhaps understandable that Lenin's 'democratic centralist' moment has been obscured. But by the time Lenin was trying to revive this democratic centralism, making an argument that liberal democracies required a different kind of 'Leninism' than had been appropriate in Russia, a new factor had emerged. Josef Stalin was gathering the forces around himself that were eventually to drown the gains of the Russian Revolution in blood, and install a monstrous dictatorship in its place. It was in November and December 1922 that Lenin wrote the lines warning the foreign communists about the 'too Russian' organizational norms being thrust upon them. But Lenin was a very sick man, and he had new and powerful enemies.

On May $25^{\text {th }}, 1922$, Lenin suffered his first crisis of arteriosclerosis: his right hand and leg became paralyzed and his speech impaired. After a long convalescence, he returned to work in the first days of October 1922. On December $13^{\text {th }}$ another attack forced Lenin to retire definitively. On March $10^{\text {th }}$, 1923, after an attack that occurred three days earlier, he finally lost the power of speech. He died on January $22^{\text {nd }}, 1924$. Behind these dates and details of Lenin's health, however, lies 'Lenin's last struggle', which was a struggle not only against illness but also, and above all, for Leninism and socialism. And never did Lenin the fighter have to fight harder or in more painful circumstances (Liebman 1975, 417-18).

As Lenin battled for his life, Stalin manoeuvred to undermine his authority, and to prevent his writings from being made public. One of the defining political issues of Lenin's life had been his insistence on the right of the oppressed national minorities, in Russia and elsewhere, to assert their own cultural and political autonomy and independence. For Lenin this was a hallmark of both self-determination and socialism. Any left project was a 
dead letter without it. From his sick bed, he became alarmed at the repression being levelled by Stalin against the oppressed nationalities in the Caucasus. In spite of being 'up against a persistent refusal to cooperate...'

He did indeed fight, wresting information and concessions from those in control of him, and preparing, bit by bit, an immense report, which he intended for the Party congress that was soon to take place... [W] hen, by a miracle of effort, Lenin managed to dictate some articles and notes, he had to fight again to get the Party leadership to publish the material that he sent to Pravda. In the Political Bureau they even discussed having a single copy of Pravda printed for Lenin's benefit, containing an article he wanted published but which they would have preferred not to make known to the general public.... Cut off... from the outside world, isolated and spied upon, it was against Stalin that Lenin was waging the most furious, most desperate but also most significant of all his struggles. What was at stake was nothing less than whether or not he would succeed in changing the course being followed by the Soviet state in a number of vital areas: bureaucratic degeneration, the excessive power wielded by the future dictator, and tendencies towards oppression of the national minorities (Liebman 1975, 419).

Lenin lost this fight, and it was left to Leon Trotsky, his closest collaborator after 1917, to continue the struggle to preserve the real lessons of the Russian Revolution from their perversion at the hands of Stalin and the state capitalist ruling class he represented.

\section{'Too Russian'}

As Stalin reinforced authoritarianism inside the Soviet Union, a parallel reinforcement of authoritarianism took place in the Communist Parties that looked to Russia for inspiration. This is a complicated story, whose outlines can only be sketched in this short article.

The organizational theses cited above - the theses that Lenin warned were 'too Russian' - were introduced to the Third Congress of the Communist International, July 12, 1921. But they were really an afterthought. At that Congress, the leading members of the Russian movement were preoccupied with other, much more pressing questions. An ultraleft and voluntarist leadership (encouraged by some leading members of the Russian Party) had captured control of much of the European communist movement, leading to a catastrophe in the 'March actions' in Germany. In March of 1921, the German Communist Party (KPD) - a real mass party with some 400,000 members (Cliff 1990, 225) - attempted a workers' 
Socialist Studies: the Journal of the Society for Socialist Studies 5(2) Fall 2009: 41-63

uprising, even though only a minority of the working class followed its lead. 'The inevitable collapse of the adventure was followed by a savage repression. The KPD was outlawed. Membership fell catastrophically to 150,000 or less and thousands of militants were imprisoned,' (Hallas 1985, 64 ) and 'tens of thousands lost their jobs' (Cliff 1990, 225). Given that the KPD was the most important communist organization outside Russia, and given that both Lenin and Trotsky were convinced that without workers' power in Germany, their situation in Russia was hopeless, this catastrophe understandably dominated the Third Congress of the Comintern, meeting as it did in the wake of these terrible events.

'A purely mechanical conception of proletarian revolution' wrote Leon Trotsky in a summation of the main lessons of the Third Congress, 'has led certain groups of comrades to construe theories which are false to the core: the false theory of an initiating minority which by its heroism shatters "the wall of universal passivity" among the proletariat. The false theory of uninterrupted offensives ... the false theory of partial battles which are waged by applying the methods of armed insurrection' (Trotsky 1972a, 295-296). For Trotsky, socialism 'can be gained only by the skilled conduct of battles and, above all, by first conquering the majority of the working class. This is the main lesson of the Third Congress' (296). In this summation of the key lessons of the Third Congress, Trotsky does not even mention the organizational question. In a separate speech on the same subject, he mentions it once, but only in passing. The key thing at the Third Congress was not party organization, but rather explaining to an impatient newly radicalized generation that it was necessary sometimes to 'strategically retreat':

In the March days [in Germany in 1921] - and I say this quite openly - we did not have behind us one-fifth or even one-sixth of the working class and we suffered a defeat... [A]fter such a defeat we must retreat... We must say to the working class... on the basis of facts we have become convinced that in this struggle we had only one-sixth of the workers behind us. But we must number at least four-sixths or two-thirds, in order to seriously think of victory; and to this end we must develop and safeguard those mental, spiritual, material and organizational forces which are our bonds with the class... [T] his signifies a strategic retreat for the sake of preparation (Trotsky 1972b, 308-309).

Here Trotsky was developing a strategic orientation that was to emerge in full flower in, what is for socialists today, the most important of the early congresses of the Communist International, the Fourth Congress. At this congress - the last where Trotsky and Lenin played a role, and the last 
Congress not to be twisted and distorted by the baneful influence of Stalinism - the delegates formulated in clear and persuasive fashion the 'united front tactic':

The united front tactic is simply an initiative whereby the Communists propose to join with all workers belonging to other parties and groups and all unaligned workers in a common struggle to defend the immediate, basic interests of the working class against the bourgeoisie.... It is particularly important when using the united front tactic to achieve not just agitational but also organizational results. Every opportunity must be used to establish organizational footholds among the working masses themselves... The main aim of the united front tactic is to unify the working masses through agitation and organization. The real success of the united front tactic depends on a movement 'from below,' from the rank-and-file of the working masses. Nevertheless, there are circumstances in which Communists must not refuse to have talks with the leaders of the hostile workers' parties, providing the masses are always kept fully informed of the course of these talks (Trotsky 1983a, 396).

This amounted to a complete turn in the orientation of radical socialists around the world. It was the magnificent obsession of Trotsky and Lenin to facilitate this turn. It was part of the enormous effort to make the political practices forged in conditions in Tsarist Russia closer to the Third World rather than the First, relevant to socialists operating in advanced capitalist societies, often in a situation of liberal democracy. In the context, this meant arguing for a 'retreat' from the extreme 'leftism' of the first years of the revolution. Hence at the Third Congress, they had a division of labour, Trotsky explaining the case for a 'retreat' in Western Europe, and Lenin explaining the case for a 'retreat' inside Russia. Trotsky's report was 'Theses of the Third World Congress on the International Situation' (Trotsky 1983b, 184-203). Lenin's report was 'Theses for a Report on the Tactics of the RCP' (Lenin 1983, 203-210), where he was intently focussed on explaining the transition to 'state capitalism' in the direction of the new Russian state - a transition made necessary by the devastation of civil war and foreign intervention.

These reports by Trotsky and Lenin were the critical documents of the Congress. There is little evidence that either of them paid very much attention to the question of party organization. The theses seem to have been drafted by a Finnish communist, Otto Kuusinen with some involvement from the Hungarian Béla Kun. ${ }^{1}$ The job of delivering the

\footnotetext{
${ }^{1}$ Thanks to John Riddell for assistance in sorting out the details by which the organizational report was prepared and delivered.
} 
Socialist Studies: the Journal of the Society for Socialist Studies 5(2) Fall 2009: 41-63

report to the Congress was given to a German by the name of Wilhelm Koenen. But the involvement of Koenen, Kun and others in the preparation and delivery of this quite important report, raises some real questions.

Koenen was an individual of minor importance in the history of that tumultuous epoch. He had been on the executive of the Independent Social Democrats (USPD) in 1920. The majority of that very large party voted in October 1920 to join the German communists (Deutscher 1977, 50). It is perhaps his affiliation with the USPD majority that temporarily pushed Koenen into the spotlight. He would soon return to the obscurity from which he came. By 1924 he was out of the German communist party, and there is some suspicion that he had been one of the 'corrupt leaders' of the USPD. $^{2}$

There is another aspect to Koenen's role that is worth noting. According to Koenen, the report that he delivered on 10 July 1921 'was assigned to me only in the course of the last week.' The person who was to have originally given the report was the Hungarian Béla Kun (Koenen n.d.). But why would Kun be given any leadership role at this Congress? The disastrous March Action, which had crushed the KPD in Germany, was in large measure carried out under his watch. Béla Kun had been 'Zinoviev's emissary' according to Tony Cliff $(1990,224)$. Grigory Zinoviev was chairman of the Comintern's executive committee and had been the leading proponent of the 'theory of the offensive' which led to the cataclysm of the March Action (Broué 1964). But Zinoviev too was not put out to pasture after what should have been a disgrace, but remained as chairman of the Comintern's executive committee. Further, it is largely due to Zinoviev that Koenen's report was passed. The first speaker to follow Koenen was a delegate from Switzerland who said that the report was 'an unsuitable basis for discussion.' He called the report 'eighteen pages of mishmash, which does indeed contain some good ideas, but is kept so vague, so blurred, that it does not deserve the name 'Theses' at all.' He moved 'to reject these Theses without discussion.' But Zinoviev intervened immediately, made a few demagogic points in support of Koenen,

\footnotetext{
${ }^{2}$ In conversation with Heinrich Brandler, who had been a leader of the KPD in the 1920s, Deutscher asks: 'How much truth was there in Trotsky's view, expressed somewhere, that already in the Lenin period, around 1920, Zinoviev introduced the corruption of leaders of foreign parties as a matter of course? At first Brandler confirms this without reservation, and mentions the names of corrupt leaders of the independents, among them the name of Koenen' (Deutscher 1977, 50).
} 
reminded the delegates 'that we are very tired,' and won the delegates to adopt the theses (Koenen n.d.).

This is a strange tale. Theses which were to become iconic in 'Leninist' organizing, were delivered by a minor figure from the German party, taking over from Béla Kun who should have been a disgraced exleader after his conduct in the March Action, and saved in the end by Gregory Zinoviev, another Comintern leader whose recent actions should have disqualified him from any leadership role. This is the context in which the Third Congress of the Comintern voted to accept the theses on organization, a bizarrely detailed text, with fifty-eight subsections, that include among other items, a universal prescription for weekly meetings, the 'duty to make reports,' the universal appropriateness of a factory cell structure for local organizing, and the need for 'enthusiastic' involvement in party campaigns. Perhaps this level of detail was felt necessary because of the inexperience of the young activists who had recently joined the Communist Parties in the west. Perhaps it reflected the obsessions of Koenen. We can only speculate. What we do know is that, in contrast to the sensitive and careful reports of Lenin and Trotsky, it reads like the worst kind of formalism and schematism, and has all the hallmarks of a report hastily thrown together and hastily passed. Lenin and Trotsky, the preeminent leaders of the early Comintern, were understandably preoccupied with bigger questions.

Now as in all reflections on history, it is best not to judge actors at one point in time with lessons that could only be learned years later. It is probable that at the time, the full measure of the March catastrophe had yet to be absorbed. That is why Trotsky was bending every effort to explain the seriousness of the situation - precisely because it was not understood. It is also the case that if in 1922 Lenin was to see these theses as 'too Russian,' in 1921 he did not yet see the problem. That year, in letters addressed to authors of the thesis - including Koenen - Lenin had said that he read the 'draft theses on the organizational question with great pleasure. I think you have done a very good job' (Lenin 1977a, 318). If one of the bizarre features of the theses is its incessant detail, Lenin's direction was to add even more!

There is another road that this analysis could take. For obvious reasons, the focus of Lenin, Trotsky and the other socialists in Russia had been on overthrowing Tsarism and challenging capitalism in their own country, a country of peasants, illiteracy, autocracy and impoverishment. The fact that even after the catastrophe of March 1921, key architects of that catastrophe like Zinoviev and Béla Kun could be allowed leadership 
Socialist Studies: the Journal of the Society for Socialist Studies 5(2) Fall 2009: 41-63

roles 'directing' the new Communist International, is quite possibly an indication that Lenin, Trotsky and other leaders of the Comintern did not really appreciate a) the scale of the disaster that had unfolded; b) the illsuited nature of the authoritarian directives which had come down from the Comintern to the German KPD; and c) the way in which both of those exposed the chasm which separated conditions in Germany from conditions in Russia. March 1921, in other words, was part of the harsh reality-check that Bolshevism encountered in its difficult move from autocratic semi-feudal Russia to capitalist and (sometimes) democratic Europe. ${ }^{3}$

If these elements weren't clear in 1921, they were quite a bit clearer one year later. By 1922 Lenin and Trotsky were starkly aware of the extent of the terrible isolation they faced. Lenin (as indicated above) and Trotsky had always been cognizant of the fact that without a revolution in the advanced countries, their revolution was doomed. But only with the defeat of the March Action did it become clear how difficult this new wave of revolution was going to be, and only after some months had passed did the scale of the catastrophe that the March Action had wreaked on the KPD and the prospects for socialism become apparent. And with their attention focussed on this huge difficulty, the gulf that separated the organizational measures appropriate to 'Russian conditions' and those appropriate to Western European conditions, became all too clear.

So when one year later, in preparing for the Fourth Congress, Lenin turned his attention again to the Kuusinen/Koenen/Kun report, he was horrified. His reaction to this document was completely different from his cursory praise of it the year previous. In the context of debilitating illness, Lenin was struggling on two fronts - to win the communist movement to the united front tactic, and to combat the Stalinist degeneration of his own party. It is clear that he saw a link between these two issues and the organization report passed just the previous year. He prefaces his remarks to the Congress by apologizing for the brevity of his speech: 'you will understand that after my lengthy illness I am not able to make a long report.' But in this short report, 'Five Years of the Russian Revolution and the Prospects of the World Revolution,' he devotes almost one-fifth of it to a criticism of Koenen's organizational document. Lenin concludes his report with the condemnation of the document, cited above: '[W]e made a big mistake with this resolution... we blocked our own road to further

\footnotetext{
${ }^{3}$ The account of the Comintern's negative role in the catastrophe of the March Action is based on Pierre Broué's magnificent The German Revolution: 1917-1923 (2006).
} 
success,' and then urges Comintern members everywhere to approach this question with a critical perspective:

[O]ur most important task today is to study and to study hard. Our foreign comrades, too, must study.... [F]irst of all, among other things they must learn to understand what we have written about the organizational structure of the Communist Parties, and what the foreign comrades have signed without reading and understanding. This must be their first task.... The resolution is too Russian, it reflects Russian experience. That is why it is quite unintelligible to foreigners, and they cannot be content with hanging it in a corner like an icon and praying to it. Nothing will be achieved that way. They must assimilate part of the Russian experience. Just how that will be done, I do not know (Lenin 1980, 431).

These are not peripheral comments by Lenin. They are his central remarks in one of his last public appearances, words wrenched out of a dying body, appealing to his followers 'to study' and to not hang the organizational resolution 'in a corner like an icon and praying to it.'4

He lost this battle. The formalistic, schematic 'too Russian' precepts for organization were in fact fossilized into an icon. Critical study of them was made almost impossible. The Leninism that emerged onto the stage of history was exactly the caricature that Lenin had feared.

But this caricature was useful to the dictatorship that was in formation. At the Fifth Congress - the first one without Lenin, and with the campaign against Trotsky now in full swing - one of the key decisions was to 'bolshevize' the non-Russian communist parties. The context was the emergence of the 'troika' of Zinoviev, Kamenev and Stalin as the heirs of the now deceased Lenin. The 'bolshevization' amounted to making universal, the authoritarian methods of the underground Bolsheviks, regardless of conditions prevailing in other countries - including liberal democracies in the advanced capitalist world. In this, Koenen's schematic theses were quite useful. The parties were to be tightly run, bureaucratically centralized operations, sections of an international party, headed of course by the Russian. The hymn to centralism by James Cannon, cited earlier, was in the context of defending this 'bolshevization' to his cothinkers in the United States. British socialist Duncan Hallas very clearly captures the essence of this campaign:

\footnotetext{
${ }^{4}$ His last public speech was delivered 22 November 1922 (Lewin 1973, 4). The speech quoted here was delivered 04 November 1922.
} 
Socialist Studies: the Journal of the Society for Socialist Studies 5(2) Fall 2009: 41-63

'Bolshevisation' was the watchword of the fifth congress of the Comintern in June-July 1924. It was the precise counterpart to the cult of the dead Lenin in the USSR and its actual content was the same: unqualified submission to the Troika as the supposed guardians of Leninist orthodoxy and hostility to all critical voices, above all to Trotsky. Naturally, this 'Leninism' had nothing in common with the spirit of Lenin's own politics (Hallas 1985, 106).

Fernando Claudin, in his monumental history of the Comintern, describes the baneful effect this had inside Communist Parties around the world. "The campaign for "Bolshevization" of the Communist parties which began in 1924 was expressed in the German party, as in the others, by a strengthening of bureaucratic centralism and a rejection of national realities' (Claudin 1975, 141). At the end, the Stalinist dictatorship had at its disposal disciplined, authoritarian parties which tragically combined sometimes brilliant work in their own working classes, with subservience to the twists and turns of the new Russian ruling class - all in the name of a perversion of the actual meaning of the term 'democratic centralism.'

\section{Conclusion}

The Stalinist Parties that selectively seized the authoritarian Leninism of the underground period and ignored the democratic Leninism of the revolutionary period - these parties have largely been swept from the stage of history. Liebman's book is a scholarly, comprehensive and devastatingly persuasive critique of that Stalinist 'moment.' His work is the necessary starting point for a reconceptualization of Lenin for socialists in the twenty-first century. But if the Stalinist parties are gone, one-sided and 'too Russian' interpretations of Leninism are not their exclusive preserve such interpretations are ubiquitous. None of the quotes from Lenin here are from secret archives. All of them are widely accessible on the web, and before the rise of the Internet were widely available in the Collected Works of Lenin. But this Lenin - the pro-fantasy Lenin who warned about the dangers of a 'too Russian' translation of the Russian Revolutionary experience - this Lenin is almost never cited. The silence on this Lenin, and the amplification of the What Is To Be Done Lenin (itself in a caricaturized form, as Lars T. Lih has so forcefully indicated) speaks volumes about the way in which Leninism migrated to the Western World.

This article began by counterposing the approach of Liebman to that of Žižek, suggesting that we need more Liebman and less Žižek in the Lenin Studies which is developing in our century. Elsewhere I have written a longer critique of Žižek's Leninism (Kellogg, 2008). For my purposes 
here, it is enough to assert that Žižek needs to not promote the 'Inner Greatness of Stalinism' but seriously to engage with the 'Inner Bankruptcy of Stalinism' so clearly demonstrated by Marcel Liebman among others. Liebman concludes his book by outlining this bankruptcy, and it is an appropriate place to conclude this article:

Of course... [Stalin and Stalinism] dressed themselves up in the finery of dialectics... But although Stalinist practice often referred to dialectics... Stalinist dialectics was merely the ideological cover for the ramblings of a short-sighted pragmatism. If Stalinism is Leninism plus administrative tyranny and plus bureaucratic terror, it is also Leninism minus dialectics. It is thus Leninism impoverished by being deprived of that leaven which has made of it, even in its mistakes, and in spite of its failures, one of the richest sources of inspiration in the fight for socialism, one of the most fruitful contributions to men's [sic] struggle for their emancipation (Liebman 1975, 448).

To fully appreciate and apply this contribution will require the socialist generation of this century to rediscover the democratic Leninism for too long obscured by the romanticization of Leninist centralism and authoritarianism.

\section{References}

Broué, Pierre. 1964. “Germany 1921: The March Action.” What Next? http://www.whatnextjournal.co.uk/Pages/History/1921.html (accessed 30 June 2009).

Broué, Pierre. 2006. The German Revolution: 1917-1923. Chicago: Haymarket Books.

Cannon, James P. 1924. "The Bolshevization of the Party." In The Workers Monthly 4, no. 1 (Nov. 1924), 34-37. Reprinted in James P. Cannon and the Early Years of American Communism: Selected Writings and Speeches, 1920-1928, 232-243. New York: Spartacist Publishing Company. Available at http://www.marxisthistory.org/history/usa/parties/cpusa/1924/10/1005cannon-bolshevization.pdf (accessed 30 June 2009).

Claudin, Fernando. 1975. The Communist Movement: From Comintern to Cominform. Markham: Penguin Books.

Cliff, Tony. 1975. Lenin, Volume I: Building the Party. London: Pluto Press. Available at Marxists Internet Archive, http://www.marxists.org/archive/cliff/works/1975/lenin1/index.htm (accessed 30 June 2009).

Cliff, Tony. 1990. Trotsky, Volume 2: 1917-1923, The Sword of the Revolution. London: Bookmarks.

Deutscher, Isaac. 1977. "Record of a Discussion with Heinrich Brandler." New Left Review I/105: 47-55. 
Socialist Studies: the Journal of the Society for Socialist Studies 5(2) Fall 2009: 41-63

Hallas, Duncan. 1985. The Comintern. London: Bookmarks. Available at Marxists Internet Archive, http://www.marxists.org/archive/hallas/works/1985/comintern/index.htm (accessed 30 June 2009).

Kanatchikov, Semyon Ivanovich. 1986. A Radical Worker in Tsarist Russia. Stanford: Stanford University Press.

Kellogg, Paul. 2008. "The only hope of the revolution is the crowd: The limits of Žižek's Leninism." International Journal of Žižek Studies 2, no. 2. Available at http://zizekstudies.org/index.php/ijzs/article/view/129/227 (accessed 30 June 2009).

Kolchin, Peter. 1987. Unfree Labor: American Slavery and Russian Serfdom. Cambridge: Harvard University Press.

Koenen, Wilhelm. n.d. "Appendix A: Report on the Organization Question," Prometheus Research Series 1, Available at http://prl.org/print/prs1/appendixa.html (accessed 30 June 2009).

Koenen, Wilhelm. 1983. "The Organizational Structure of the Communist Parties, the Methods and Content of Their Work: Theses." In Theses, Resolutions \& Manifestos of the First Four Congresses of the Third International, ed. Alan Adler, 234-260. London: Pluto Press, 1983. Available at Marxists Internet Archive, http://www.marxists.org/history/international/comintern/3rdcongress/organisation/guidelines.htm (accessed 30 June 2009).

Lenin, V.I. 1977a. "Letter to O.W. Kuusinen and W. Koenen." In Collected Works, Volume 42. Moscow: Progress Publishers, 1977, 318-319.

Lenin, V.I. 1977b. "Political Report of the Central Committee, March 7," in Collected Works, Volume 27. Moscow: Progress Publishers, 1977, 87-109. Available at Marxists Internet Archive, http://www.marx.org/archive/lenin/works//1918/7thcong/01.htm (accessed September 15, 2009).

Lenin, V.I. 1978a. "Party Organisation and Party Literature." In Collected Works, Volume 10. Moscow: Progress Publishers, 1978, 44-49. Available at Marxists Internet Archive, http://www.marxists.org/archive/lenin/works/1905/nov/13.htm (accessed 30 June 2009).

Lenin, V.I. 1978b. "Report on the Unity Congress of the Russian Social-Democratic Labour Party." In Collected Works, Volume 10, V.I. Lenin. Moscow: Progress Publishers, 1978, 317-382. Available at Marxists Internet Archive, http://www.marxists.org/archive/lenin/works/1906/rucong/index.htm (accessed 30 June 2009).

Lenin, V.I. 1978c. "Freedom to Criticise and Unity of Action." In Collected Works, Volume 10, V.I. Lenin. Moscow: Progress Publishers, 1978, 442-443. Available at Marxists Internet Archive, http://www.marxists.org/archive/lenin/works/1906/may/20c.htm (accessed 30 June 2009). 
Lenin, V.I. 1980. "Fourth Congress of the Communist International." In Collected Works, Volume 33, V.I. Lenin. Moscow: Progress Publishers, 1980, 415-432. Available at Marxists Internet Archive, http://www.marxists.org/archive/lenin/works/1922/nov/04b.htm (accessed 30 June 2009).

Lenin, V.I. 1983. "Theses for a Report on the Tactics of the RCP." In Theses, Resolutions \& Manifestos of the First Four Congresses of the Third International, ed. Alan Adler, 203-210. London: Pluto Press, 1983.

Lewin, Moshe. 1973. Lenin's Last Struggle. London: Pluto Press.

Liebman, Marcel. 1970. The Russian Revolution: The origin, phases and meaning of the Bolshevik Victory. London: Jonathan Cape.

Liebman, Marcel. 1975. Leninism Under Lenin. London: Merlin Press.

Lih, Lars T. 2006. Lenin Rediscovered: 'What is to be Done?' in Context. Boston: Brill.

Trotsky, Leon. 1972a. "The Main Lesson of the Third Congress." In The First Five Years of the Communist International: Volume I, Leon Trotsky. New York: Monad Press, 1972. Availableat Marxists Internet Archive, http://marxists.org/archive/trotsky/1924/ffyci-1/ch25.htm (accessed 30 June 2009).

Trotsky, Leon. 1972b. "Report on 'The Balance Sheet' Of the Third Congress of the Communist International." In The First Five Years of the Communist International: Volume I, Leon Trotsky. New York: Monad Press, 1972. Available at Marxists Internet Archive, http://marxists.org/archive/trotsky/1924/ffyci-1/ch26.htm (accessed 30 June 2009).

Trotsky, Leon. 1983a. "Theses on Comintern Tactics." In Theses, Resolutions \& Manifestos of the First Four Congresses of the Third International, ed. Alan Adler, 388-399. London: Pluto Press, 1983. Available at Marxists Internet Archive, http://www.marxists.org/history/international/comintern/4thcongress/tactics.htm (accessed 30 June 2009).

Trotsky, Leon. 1983b. "Theses of the Third World Congress on the International Situation and the Tasks of the Comintern." In Theses, Resolutions \& Manifestos of the First Four Congresses of the Third International, ed. Alan Adler, 184-202. London: Pluto Press, 1983. Available at Marxists Internet Archive, http://www.marxists.org/archive/trotsky/1924/ffyci-1/ch21.htm (accessed 30 June 2009).

Ulam, Adam B. 1971. The Bolsheviks. Toronto: The MacMillan Company.

Žižek, Slavoj. 2002. V.I. Lenin, Revolution at the Gates: A Selection of Writings from February to October 1917. New York: Verso. 